\title{
Efficiency Marketing of Onion In Bantul Regency
}

\author{
Wulan Priantika ${ }^{1}$, Suhatmini Hardyastuti' ${ }^{2}$ Irham $^{3}$ \\ ${ }^{1}$ Postgraduate Agribusiness Management, Faculty of Agriculture, Universitas Gadjah Mada \\ ${ }^{2,3}$ Faculty of Agriculture, Universitas Gadjah Mada Jl. Flora No. 1 Bulaksumur (55281), Yogyakarta, \\ Telp. (0274) (555675)
}

Received: 4 March 2019; Revised: 2 March 2021; Accepted: 10 March 2021

\begin{abstract}
Onion is one of the potential horticultural plants in Yogyakarta Special Region. Onion production center is located in District Saden and Imogiri District, Bantul regency. This research has objectives to (1) know the onion marketing chain in Bantul Regency and (2) to know the most efficient marketing channel using Acharya method. Respondents were randomly selected as many as 60 onion farmers in Bantul District. Snowball method is used to get two wholesalers, three merchant collectors, and three retailers by following the distribution of onion sales from farmers to consumers. The results showed that the onion marketing chain in Bantul district consists of three marketing channels. The most abundant onion chain of marketing compositions in Bantul District is farmers-wholesalers-collectors-retailers-consumers, farmerswholesalers-collectors, and farmers- collectors-retailers. Marketing on onion in Bantul Regency is done most efficiently in the third marketing channel that is farmers-collectors-retailers. This research is expected to give information about the marketing chain of onion in Bantul regency.
\end{abstract}

Keywords: efficiency; marketing chain; red onion

\section{How to cite:}

Priantika, W., \& Hardyastuti, S. (2021). Efficiency Marketing of Onion In Bantul Regency. HABITAT, 32(1), 11-16. https://doi.org/10.21776/ub.habitat.2021.032.1.2

\section{Introduction}

Onion is one of the potential horticultural commodities. This is because until now onion commodity widely and commonly has been developed by society and have a good enough market opportunity. The prospect of onion development is excellent in terms of increasing demand as the population increases (Hartono and Masyhuri, 2013.). This commodity is also a source of income and employment as well as able to contribute significantly to the development of the region (Susanawati,et al., 2017) . Yogyakarta Special Province is one of the areas with a large onion potential the production centers located in Bantul District, Saden District and Imogiri District.

Production and consumption gaps do not only occur in terms of quantity but also in terms of time, causing the onion import continues to occur. Onion season is generally occured during the dry season, while in the off-season farmers

*Correspondence Author.

E-mail: wulanpriantika.wp@gmail.com rarely plant onion because they are faced with a high disease attack (Purba and Astuti, 2013). In addition, during the rainy season, the price of seeds is relatively high due to the decrease availability of the seeds (Putrasamedja, 2010). Until now, the availability of onion is still below the needs, especially in the rainy season. This causes the price of the onion in the market often soaring, even causing inflation every year. The influence of seasons does not only lead to fluctuate the production but also affect the price fluctuation (Susanawati et al., 2015). The perishable nature of perishable onion products which are consumed throughout the year causes rapid price changes ( Sukesi, et al., 2014).

The potential of onion commodities in Bantul regency needs to be supported by an efficient marketing system so that the onion market can provide maximum benefits for the market participants, especially farmers. The onion marketing system is based on the market mechanism, where price formation occurs through the balance of demand and supply that occurs in the market. The relatively fast price changes are expected to be responded quickly by 
market participants so that market participants can make the right decision and the market becomes more efficient. (Asmara and Ardhiani, 2010).

The number of actors involved in the onion marketing chain of Bantul Regency can make the chain unfavorable because each actor has their own level of importance, thus raising a number of issues among the marketing actors. The existence of price differences at a consumer level and at the level of farmers is very striking, the difference occurs because of the cost in the process of marketing onion. Based on these conditions, this research has objectives (1) to know the onion marketing chain, and (2) to know the most efficient marketing channels using Acharya method.

\section{Research Method}

This research was conducted in Bantul Regency as the center of onion in DIY. The selection of this location was done deliberately by considering Bantul Regency as a production center of the onion. The research location are in two subdistricts, those are Saden and Imogiri Subdistrict. The data collected consists of primary data and secondary data. Primary data were obtained by interviewing the farmers, middlemen, merchant collectors and onion retailers. The number of respondents taken by the researchers is 60 onion farmers located in Saden and Imogiri Subdistrict using simple random sampling method. Merchant samples were taken using snowball (snowball sampling) technique by following the farmers in selling onions. In taking snowball sampling, initial identification begins with a person or case included in the study criteria. Then, based on the direct or indirect link in a network, the next respondent or next sample unit can be found (Nurdiani, 2014). The research was conducted in April - December 2016. This research is a part of grant research program of Faculty of Agriculture of Universitas Gadjah Mada Yogyakarta.

\section{A. Analysis of marketing chain condition}

Descriptive analysis is used to trace the marketing chain by onion farmers in Bantul District. Descriptive analysis method used to examine the status of human groups, objects, a set of conditions, a system of thought, or a class of events in the present (Syah, 2010). This method describes a systematic, factual and accurate event about the facts, properties, and relationships between the phenomena studied.

\section{B. Analysis of marketing efficiency}

While to know the efficiency of marketing analysis using Acharya method. Marketing Efficiency Analysis consists of:

\section{1) Marketing Margin}

The marketing margin is the price difference received by the farmer at a price paid by the consumer (Jumiati, E., et al., 2013). Mathematically, it can be formulated as follows:

$$
\begin{aligned}
& \mathrm{Mi}=\mathrm{Psi}-\mathrm{Pbi} \\
& \mathrm{Mi}=\mathrm{Ci}+\pi \mathrm{i} \\
& \mathrm{Psi}-\mathrm{Pbi}=\mathrm{Ci}+\pi \mathrm{i} \\
& \Pi \mathrm{i}=\mathrm{Psi}-\mathrm{Pbi}-\mathrm{Ci} \\
& \mathrm{MT}=\Sigma \mathrm{Mi}
\end{aligned}
$$

Where:

$$
\begin{array}{lll}
\mathrm{Mi} & = & \text { Marketing margin on the } \mathrm{i} \\
& & \text { level market } \\
\mathrm{Psi} & = & \text { The selling price on the i-level } \\
& \text { market } \\
\mathrm{Pbi} & = & \text { The purchase price at the } \mathrm{i} \\
& \text { level market } \\
\mathrm{Ci} & = & \text { The cost of the i-level } \\
& \text { marketing agency } \\
\text { Пi } & = & \text { The profit of the i-level } \\
& \text { marketing agency } \\
\text { MT } & = & \text { Total margin } \\
\mathrm{I} & = & 1,2,3, \ldots . ., \mathrm{n}
\end{array}
$$

\section{2) Ratio of Profits and Costs}

The ratio of profits and costs show the comparison between the cost incurred and the profit generated. The distribution of profit and cost ratio for each marketing institution can be formulated as follows: Where:

Profit and Cost Ratio (\%) $=\Pi$ / Ci x 100\%

$$
\begin{aligned}
\Pi & =\text { profit on i marketing agency } \\
& (\mathrm{Rp} / \mathrm{kg}) \\
\mathrm{Ci} & =\text { marketing cost at the } \\
& \text { institution level } \mathrm{i}(\mathrm{Rp} / \mathrm{kg})
\end{aligned}
$$

\section{3) Marketing Efficiency using Acharya Method}

The value is derived from the price of farmers divided by the sum of marketing costs and marketing margins that can be formulated as follows (Pradesh, 2010):

Where:

$$
\mathrm{ME}=\mathrm{PF} /(\mathrm{MC}+\mathrm{MM})
$$

$$
\text { ME = Marketing efficiency }
$$

$\mathrm{PF} \quad=$ Price from farmers 


$$
\begin{array}{ll}
\mathrm{MC} & =\text { Marketing costs } \\
\mathrm{MM} & =\text { Margin marketing }
\end{array}
$$

\section{Results and Discussion}

\section{A. Onion Marketing Chain}

The actors involved in the onion marketing chain in Bantul District are all people involved in the marketing channels of onion from the farmers to the consumers. The perpetrators of the onion marketing chain include farmers, wholesalers, collectors, retailers, consumers. The middleman in Saden and Imogiri Sub-districts amounted to two people spread in both sub-districts. The wholesale is the closest marketing institution to the farmer. The wholesales usually take onions during the day or late afternoon after harvesting or the next morning. The process of shipping onions to the middlemen is mixed. There are farmers who deliver their own red onions with the services of pikul and there is a middleman who picks his own onion farmers by using their own vehicles. The collecting traders were three people selling in the markets of both Imogiri and Saden sub-districts. The average merchant buyers buy red onions from the middleman but there also buy it directly from the farmers. Retailers have three people, most of these retailers selling in traditional markets in Imogiri and Saden subdistricts, while few of them selling outside Bantul district. The marketing chain that produces onion and most commonly found in Bantul Regency.

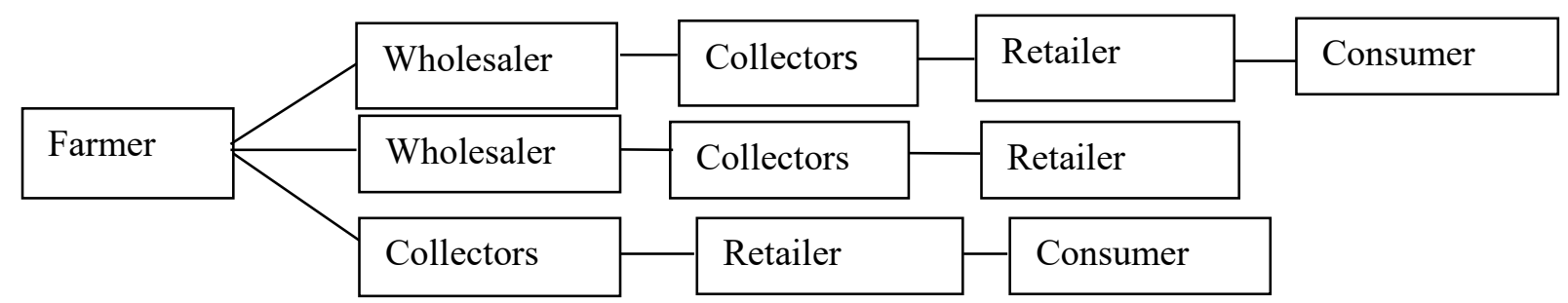

Figure 1. Onion marketing chain in Bantul regency

There are three channels of onion marketing in Bantul district:

\section{1) Farmers - Wholesalers - Collectors - Retailers - Consumers}

This marketing chain is the dominant marketing chain of onion in Bantul Regency with a percentage of $55.76 \%$ between farmers and merchants. Farmers will sell red onions to the brokers or brokers who have the highest bargaining value of onion, then to the merchant of the collectors and will deposit the onion to the merchant's subscription. Then, the merchant sell it to the consumer. In this marketing chain, the wholesaler is the price maker of the onion.

\section{2) Farmers-Wholesalers-Retailers}

This marketing chain is located in the village that has middlemen of Bantul Regency with a percentage of $40.38 \%$. The onion will be sold by the middleman to the collectors from the collectors and then resold to the retailers. These retailers are a trader in Bantul District, some of these retailers will usually sell more onions outside Bantul district. The price given by the merchant in the district is the same price given by the collecting merchant in the previous marketing chain.

\section{3) Farmers - Collectors - Retailers}

The marketing chain of farmers - retailers are the kind of onion marketing chain which is the least available in Bantul District with 3.8\% percentage. Farmers who sell onion are farmers who have excess onion after being sold to merchant collectors.

\section{B. Onion Marketing Efficiency}

\section{1) Marketing Margin}

Marketing margin represents the difference between the selling price and the purchase price of each marketing agency. This difference occurs because each marketing agency performs marketing functions that are included in the component of marketing costs. The onion marketing costs consist of packaging cost, storage cost, transportation cost, sorting cost, grading cost, and weighing cost. Any difference in activities in any marketing agency will cause the difference between the selling price of one institution to another. The more marketing agencies involved in channeling a commodity will lead to a higher marketing cost, price differentials at the consumer level and higher producer prices. One of the indicators used to determine the quality of the system is the margin. 
The lower the margin, the higher the price received by the farmer and vice versa. The margin will be different for each person because each has a different price. Calculation of each component can be seen in Table 1 .

Table 1. Marketing Margin.

\begin{tabular}{lrrrrrr}
\hline \multirow{2}{*}{$\begin{array}{c}\text { Marketing } \\
\text { Channel }\end{array}$} & \multicolumn{2}{c}{ Margin at the Marketing Institution } & $\begin{array}{c}\text { Total } \\
\text { Marketing } \\
\text { Cost }\end{array}$ & $\begin{array}{c}\text { Total } \\
\text { Profits }\end{array}$ & $\begin{array}{c}\text { Total } \\
\text { Margin }\end{array}$ \\
\cline { 2 - 7 } & Wholesalers & Collectors & Retailers & & & \\
\hline 1 & 5,000 & 2,000 & 1,500 & $2,052.50$ & $7,642.56$ & 8,500 \\
2 & 7,000 & 2,000 & 1,700 & $2,541.78$ & $9,451.81$ & 10,700 \\
3 & & 5,000 & 1,800 & $2,250.31$ & $2,549.19$ & 6,800 \\
\hline
\end{tabular}

From the calculation above, it can be seen that the marketing channel with the lowest functional cost and the total margin in the onion marketing chain is the third channel because red onions are distributed from farmers to collectors without going through middlemen, which means that this channel is the shortest channel.
Meanwhile, marketing channel 2 is a marketing channel that has the largest total margin value, this is because this the marketing channel is long and the cost of functional issued is also quite large, since the middleman takes a big enough profit.

\section{2) Value of profit ratio}

Table 2. The Ratio of Profit and cost values in the onion marketing chain.

\begin{tabular}{|c|c|c|c|c|c|}
\hline \multirow{2}{*}{$\begin{array}{c}\text { Marketing } \\
\text { Channel }\end{array}$} & \multicolumn{4}{|c|}{ The Ratio of Profit and cost } & \multirow{2}{*}{ Total } \\
\hline & Farmers & Wholesalers & Collector & Retailers & \\
\hline 1 & 2.33 & 5.64 & 3.25 & 1.72 & 3.72 \\
\hline 2 & 1.76 & 6.44 & 2.87 & 1.26 & 3.71 \\
\hline 3 & 2.84 & & 0.99 & 1.4 & 1.13 \\
\hline
\end{tabular}

The highest profit-to-cost ratio value is found in the marketing agency of the middleman in the two marketing chains, which is 6.44 . This is because the middleman has a high profit with lower marketing cost. Meanwhile, the lowest value is on the third distributed collectors, with the value of profit to cost ratio is 0.99 . The total value of the highest ratio is owned by channel one that is equal to 3.72 . This value is obtained because the marketing chain one is the most widely used marketing chain in Bantul District, thus it encourages the perpetrators of this marketing chain to take advantage of greater.

\section{3) Acharya Method}

Marketing efficiency needs to be known to identify whether the marketing channel of a product is already efficient or not. In order calculate the efficiency of red onion marketing channel in Bantul Regency, it can use Acharya method. The efficiency value of this method is derived from the price comparison received by the producer at the marketing cost plus the profit margin of each marketing agency. Channel with the highest efficiency value is the most efficient marketing channels.

Marketing efficiency needs to be known to identify whether the marketing channel of a product is already efficient or not. In order to calculate the efficiency of red onion marketing channel in Bantul Regency, we can use Acharya method. The efficiency value of this method is derived from the price comparison received by the producer at the marketing cost plus the profit margin of each marketing agency. Channel with the highest efficiency value is the most efficient marketing channel.

From Table 3. according to the calculation, the highest value of marketing efficiency ratio is found on channel 3 , this channel has a marketing efficiency index of 3.57. This happens because this channel is the shortest channel and the selling price is higher for the farmer compared to the channel 1 and channel 2. However, the cost incurred is also for a smaller marketing. Marketing channe 3 is the most efficient marketing channel. However, marketing channel 3 is rarely in used because the average farmers 
prefer to do marketing onion with channel 1 and channel 2. This is because the farmers already have a trust to the perpetrators of marketing channels 1 and marketing channel 2 .

Table 3. Onion Marketing Efficiency in Bantul District

\begin{tabular}{|c|c|c|c|}
\hline $\begin{array}{l}\text { Marketing } \\
\text { Chain }\end{array}$ & $\begin{array}{c}\text { Channel } 1 \\
\text { Value } \\
\text { (Rp/kg) }\end{array}$ & $\begin{array}{c}\text { Channel } 2 \\
\text { Value } \\
\text { (Rp/kg) }\end{array}$ & $\begin{array}{c}\text { Channel 3 } \\
\text { Value } \\
\text { (Rp/kg) }\end{array}$ \\
\hline \multicolumn{4}{|l|}{ Farmer } \\
\hline Selling price & 20,000 & 18,000 & 25,000 \\
\hline \multicolumn{4}{|l|}{ Wholesaler } \\
\hline Purchase Price & 20,000 & 18000 & \\
\hline Marketing & 752.43 & 940.68 & \\
\hline Cost & & & \\
\hline Selling price & 25,000 & 25000 & \\
\hline Margin & 5,000 & 7000 & \\
\hline $\begin{array}{l}\text { Marketing } \\
\text { efficiency } \\
\text { index }\end{array}$ & 3.47 & 2.26 & \\
\hline \multicolumn{4}{|l|}{ Collector } \\
\hline Purchase Price & 25,000 & $\begin{array}{r}25 \\
000\end{array}$ & 25000 \\
\hline $\begin{array}{l}\text { Marketing } \\
\text { Cost }\end{array}$ & 750.07 & 850.60 & 1500.81 \\
\hline Selling price & 27,000 & 27000 & 28000 \\
\hline Margin & 7,000 & 9000 & 5000 \\
\hline $\begin{array}{l}\text { Marketing } \\
\text { efficiency } \\
\text { index }\end{array}$ & 2.58 & 1.82 & 3.84 \\
\hline \multicolumn{4}{|l|}{ Retailer } \\
\hline Purchase Price & 27,000 & $\begin{array}{r}27 \\
000\end{array}$ & 28000 \\
\hline $\begin{array}{l}\text { Marketing } \\
\text { Cost }\end{array}$ & 550 & $\begin{array}{r}75 \\
0.50\end{array}$ & 750 \\
\hline Selling price & 28,500 & 28700 & 29800 \\
\hline Margin & 85,00 & 10700 & 6800 \\
\hline $\begin{array}{l}\text { Marketing } \\
\text { efficiency } \\
\text { index }\end{array}$ & 2.21 & 1.57 & 3.31 \\
\hline $\begin{array}{l}\text { Average } \\
\text { Marketing } \\
\text { efficiency } \\
\text { index }\end{array}$ & 2.75 & 1.88 & 3.57 \\
\hline
\end{tabular}

\section{Conclusion}

The most abundant onion marketing chain composition in Bantul District consists of three, those are farmers-wholesalers-collecting tradersretailers-consumers, farmers-wholesalers-traders of collectors-retailers and farmers-collectors traders-retailersOf the three marketing chains as much as one of the most widely used chains of suppliers, the marketing chain is a consumertanker-retailer-retailer. The highest marketing margin that occurs in the two marketing chains, and the lowest marketing margin that occurs in the chain of marketing channel three. The third channel is the channel with the lowest margin, and few use this marketing chain. The highest profit-to-cost ratio value is found in the marketing agency of the middleman in the marketing chain of two, while the highest total ratio value is owned by channel one. From the results of marketing efficiency analysis on shallot in Bantul district with Achary method states that the most effective marketing chain is in chain marketing on channel three because this channel is the shortest channel and the selling price of shallots at the farm level has the highest selling price value. To increase the share of prices received by farmers, a shorter marketing channel should be pursued

\section{References}

Asmara, R., \& Ardhiani, R. (2010). Integrasi pasar dalam sistem pemasaran bawang merah. Agricultural Socio-Economics Journal, 10(3), 164.

Hartono, S., \& Masyhuri, M. (2013). Efficiency Allocative Nion Farming In Tye District Bantul. Agro Ekonomi, 24(2), 138-147.

Jumiati, Elly; Darwanto, Dwidjono Hadi; Hartono, S. M. (2013). Analisis Saluran Pemasaran dan Marjin Pemasaran Kelapa Dalam Di Daerah Perbatasan Kalimantan Timur. Agrifor, XII(1), 1-10. https://doi.org/1412 - 6885

Nurdiani, N. (2014). Teknik Sampling Snowball Dalam Penelitian Lapangan. ComTech Desember, 5(2), 1110-1118. Retrieved from https://media.neliti.com/media/publications /165822-ID-teknik-sampling-snowballdalam-penelitia.pdf

Purba, R., \& Astuti, Y. (2013). Paket teknologi bawang merah di luar musim tanam di Pandeglang Banten. Agritech: Jurnal Fakultas Pertanian, 15(2).

Putrasamedja, S. (2010). Pengujian Beberapa Klon Bawang Merah Dataran Tinggi (Clones Testing of Some Highlands Shallots). 
Sukesi, H., Rahayuningrum, N., \& Widayanti, T. (2014). Analisis pemecahan oversupply bawang merah, kasus Brebes. Bul Ilm Penelit Pengemb Perdagang, 2(1), 45-55.

Susanawati, S., Jamhari, J., \& Masyhuri, M. (2015). Price behavior and market integration of shallot in Java Indonesia. International Journal of Agriculture System, 3(2), 193-204.

Susanawati, S., Jamhari, J., Masyhuri, M., \& Hadi Darwanto, D. (2017). Identifikasi Risiko Rantai Pasok Bawang Merah di Kabupaten Nganjuk. AGRARIS: Journal of Agribusiness and Rural Development Research, $3(1)$. https://doi.org/10.18196/agr.3140

Syah, H. (2010). Pengantar Umum Metodologi Penelitian Pendidikan Pendekatan Verivikatif. Pekanbaru: Suska Pres. 